\title{
Location, Pattern of Arrangement, and Physical Elements of Open Space in the Ifolia Cluster, Bekasi
}

\author{
Hartanto Budiyuwono ${ }^{1}$ \\ ${ }^{1}$ Lecturer of Architecture Program, UNPAR, Bandung, Indonesia \\ Correspondence: Hartanto Budiyuwono, Parahyangan Catholic University, Jl. Ciumbuleuit 94, Bandung, Indonesia. \\ E-mail: hh2611833@gmail.com
}

\author{
Received: May 9, 2019 Accepted: May 30, 2019 Online Published: June 18, 2019 \\ doi:10.5539/res.v11n3p20 URL: https://doi.org/10.5539/res.v11n3p20
}

\begin{abstract}
Each public open space of the housing cluster has different locations, arrangement patterns, and physical elements so that the social interactions between occupants that occur in each open space are different. Therefore, it is necessary to know how this open space affects social interactions that occur. The method used in the research is qualitative descriptive. Conduct surveys to figure the conditions that occur in the field. Then find the relationship between literature and field conditions related to open space and social interaction with users. From the results of the study, it is known that the place, structuring pattern, and physical elements of space are open to influence the social interaction of residential residents. However, from the user community, the physical element of an open space is the most influential to the social interaction of residents. Without the physical elements that encourage occupant activity, there will be no social activities and interactions in the open space.
\end{abstract}

Keywords: location, pattern of arrangement, physical elements, public open space

\section{Introduction}

Damai Putra is a developer company in the field of housing, commercial building and city development. Established on April 30, 1981. (Profile of Damai Putra | Damai Putra Group). In 1987 Damai Putra introduced Kota Harapan Indah to Jakarta and Bekasi. At present the area of Harapan Indah City covers more than 2,200 hectares at the east gate of Jakarta (Figure 1).

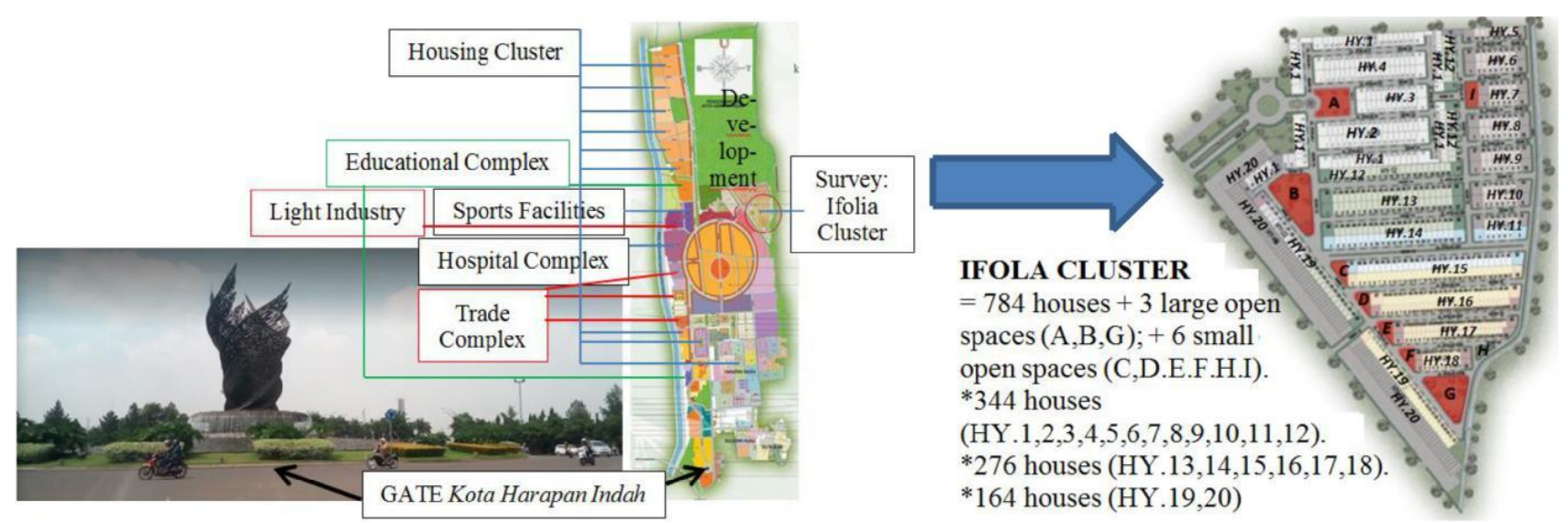

Figure 1. Arcamanik Housing and Arcamanik Sport Center Entrance

For this reason, a survey in the city expected to beautiful about its housing cluster which reached 784 houses. Housing clusters are often equipped with public open spaces to accommodate the activities and social interactions of its residents. All business sectors of procurement, supply, development in Indonesia, such as the Damai Putra that is under the real estate sector of Indonesia (REI). The Indonesian Real Estate Company Association (REI) established on Friday, February 11, 1972 in Jakarta. March 18, 1972 DKI Jakarta Governor Lieutenant General. TNI. Ali Sadikin issued Decree No.638/A/K/BKD/72 whose contents the establishment of REI living in Jakarta (http://www.rei.or.id/sejarah.php).

Continuously driven by time, on March 27, 1972 REI members state in the form of a memorandum containing contents, 
entrepreneurs in the real estate sector in Indonesia agreed to form a forum called "Indonesian Real Estate Entrepreneurs Association". REI, which now consists of thousands of large entrepreneurs, small entrepreneurs throughout the archipelago has succeeded in appearing skillfully, including as government partners, as housing development in Indonesia. In fact, the presence and progress of $R E I$ is often used as a measure in measuring economic and monetary temperatures in Indonesia. In fact $R E I$ has been active in the vibrant real estate and property industry, especially construe settlements in Indonesia. In general, population explosions occur in developing countries, including in Indonesia. One city that predicted to population explosion is the city of Bekasi (https://www.kompasiana.com/nabilrizki/5a2d1bc12a5823509c672ca2/ledakan-penduduk-mengancam-kota-bekasi). In its development, Bekasi as a buffer for the Province of Jakarta is increasingly being looked at by migrants from various regions. Every year the City of Bekasi experiences a significant increase in the population (https://gobekasi.pojoksatu.id/2017/03/10/20-tahun-kota-bekasi-jumlah-penduduk-dari-masa-ke-masa/).

Based on the data obtained, population of Bekasi (before divide the City and Regency) in 1961 reached 691,192 people. Then it increased in 1971 to 830,721 people, in 2015 the latest data collected by BPS, the population reached 2,733,240 million (http://wartakota.tribunnews.com/2018/08/05/lima-tahun-penduduk-kota-bekasi-bertambah-1-juta-jiwa). The population in 2016 has amounted to 2,803,283 people, city of Bekasi has included cities with high density with a number of 13,318 people/square kilometers. This has led to a large number of deliberately created housing developments providing ample open spaces for residents of the housing complex. These open spaces besides being ready in the form of plants, good greening is also provided as a place to exercise, take a walk or play a game. With the aim to increase fresh air, and cut saturation in the city center.

\section{Theoretical Review}

But in reality, some public open spaces in the cluster have not been used effectively by residents so as not to encourage take place social interaction between residents (Stevens, Q. 1997) (Rapoport, Amos. 1977). Surrounded by increasingly new technology and incoming globalization as well as in Indonesia, especially in urban areas raises problems for the interaction and behavior of urban communities, especially in housing complex (Madanipour, Ali. 2003). In housing complexes are generally inhabited by a family, which includes parents (father and mother) and some of their children, and often assisted by domestic helpers. This housemaid does housework, such as washing clothes, cleaning the house (Budiyuwono, Hartanto. 2014). In urban housing this is very visible, where a person does not know each other or interact with their neighbors. One of the efforts of developers to overcome this problem in urban housing is to give public open space as a facility that encourages social interaction between residential residents (Zhang, Wei. 2009). Public open space is a shared property that need to carry out functional activities and accessed by the public directly in a certain period or indirectly in an indefinite period (Carr, Stephen. 1992). Can be in the form of landscaping, roads, pedestrian spaces, parks, parking lots, and recreation areas or in other words, these spaces are specifically planned and provided for interacting functions (Shirvani, Hamid. 1985). Open space in housing consists of an active garden that accommodates human activities, a passive garden that can only be enjoyed by its beauty but cannot be functioned by residents, pedestrians, and fields which in the form of lawns, pavements, and equipped with supporting activities. To be in open space in the middle, close to the entrance, or spread across the entire cluster (Untermann, Richard. 1977). There are two physical elements of the landscape, namely soft landscape that uses vegetation and hard landscape elements which include pavement in welds (Carmona. 2003). The process of social interaction can seem starting with exist activities that invite take place other activities by the user, so that ultimately creates social interaction between users of public open space. Activities that need be done are optional activities, and social activities (Gehl, Jan. 1987). Social interactions that occur in open spaces will form patterns of social interaction, namely individual groups where residents do not interact with their neighbors, secondary groups where residents only interact with neighboring neighbors, and primary groups where all residents can interact with all residents in their housing environment (Thiberg, Sven.1985). Therefore, the developer of the Ifolia Cluster in Kota Harapan Indah, Bekasi has several open spaces that have different locations, arrangement patterns, and physical elements. Already put some public open spaces in a cluster to increase social interaction in a cluster, but often not all public open spaces in a cluster utilized by cluster residents effectively and in the end some public open spaces that have no effect in increasing the social interaction of cluster residents (Rapoport, Amos. 1977).

\section{Methodology}

The method used in this study is descriptive qualitative. First, observations made to find out the phenomena and problems that occur in the field. After that, data collection and interviews carried out in the form of observations of physical activities and elements found in open spaces found in both Ifolia clusters and interviews with open space users. After that, a data analysis of the theory obtained from the literature study was then carried out drawn into a conclusion that answered create the existing problems. 


\section{Case Study}

The Ifolia cluster open space consists of 8 open spaces, namely: outdoor A, outdoor B, outdoor C, outdoor D, outdoor E, outdoor F, outdoor G, outdoor I (Figure 2).

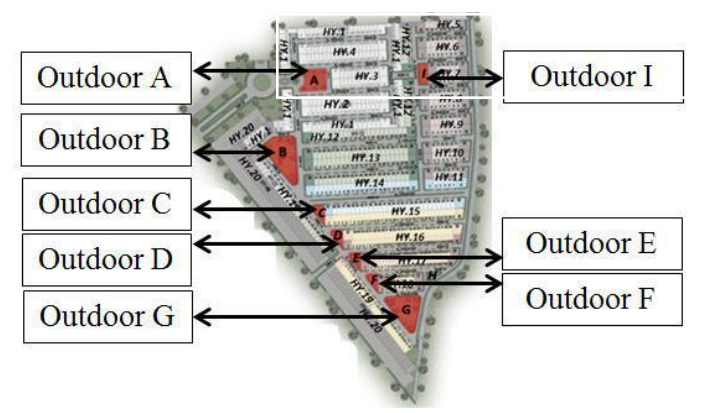

Figure 2. Outdoor A,B,C,D,E,F,G,I

The perpetrators of activities in this open space, are residents of the house. Almost all residents of the house are parents and children. All residents equipped with housemaids, who do not always stay overnight. Family members consisted of father and mother, who at least one family member worked outside the house, had gone out of the house early in the morning and returned home until evening. If those who still have a baby, usually the housewife takes care of it, sometimes assisted by the nurse who stays in the baby's bedroom. The children go to school every day.

Therefore, activities in the open space carried out only on holidays which do not go out-of-town. Or if there is free time outside of school time. For residents who are already unemployed who generally jog early in the morning or late in the evening, given the heat of the sun in the cities of Bekasi and Jakarta, for this reason many green plants need in the open space.

\subsection{Outdoor A, B and $G$}

Positioning open space A and B, the Ifolia cluster is in the middle of a group of houses around it. This open space A and B is larger than the open space C, D, E, F and I. This vast area of land process for activities so that residents can play, exercise, be equipped with creative assistive devices.

This is what makes the interested people from other places who happen to know about this outdoor. Generally people interest in the design of physical elements in this open space. The reality is that the users are mostly residents of the surrounding houses, whether they are family members, or helpers who work in these homes.

\section{The design form of Room A consists of 3 elements of activity (Figure 3).}

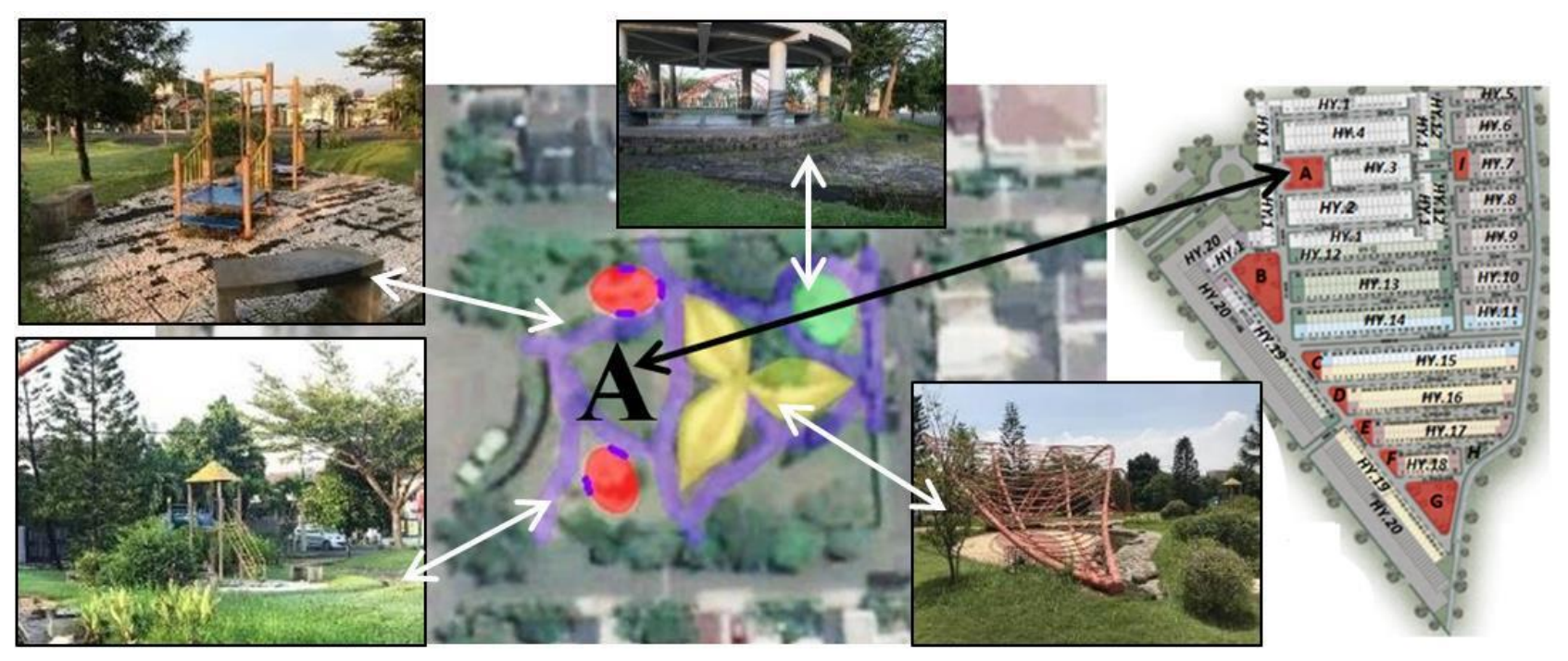

Figure 3. children's games (red), garden chairs (blue), and gazebos (green) 
The physical elements that most invite users to move in open space A are children's games (red), then garden chairs (blue), and gazebos (green) which are sometimes used by residents around for community meetings.

The design form of Room B consists of 3 elements of activity (Figure 4).

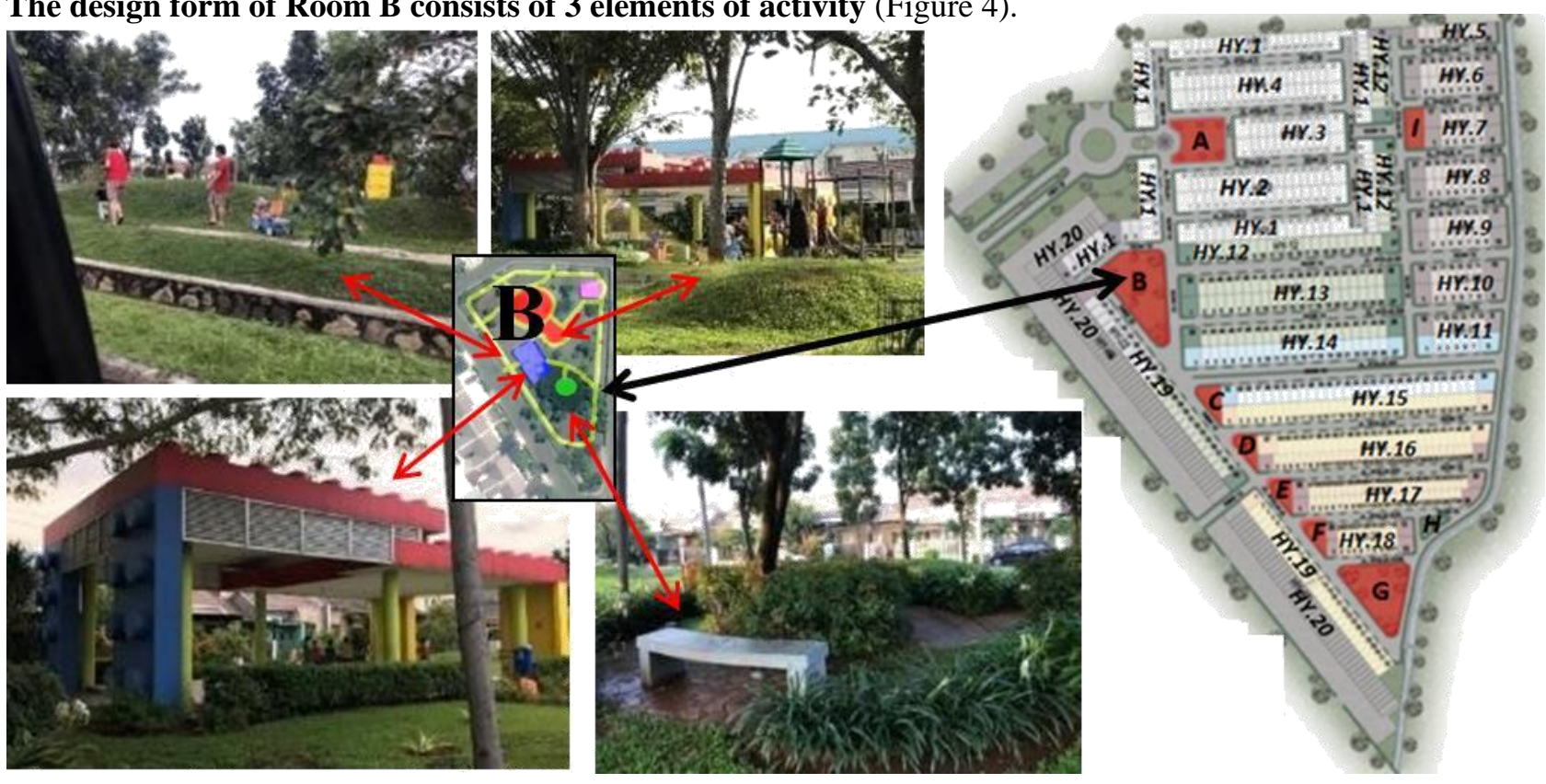

Figure 4. Children's games and garden chairs (red), gazebos (blue), pedestrian pathways (yellow)

The physical elements that most invite users to do activities in open space B are children's games and garden chairs (red), then lego gazebos that are often used by children to play ball (blue), pedestrian pathways that are often used for walking or jogging (yellow). Lego is a type of small plastic lump game that is well-known in the world especially among children or adolescents regardless of male or female. These blocks and other pieces arranged into any model. This game tool by the LEGO Company from Denmark (https://id.wikipedia.org/wiki/Lego).

\section{The design form of Room $\mathbf{G}$ consists of 3 elements of activity (Figure 5).}

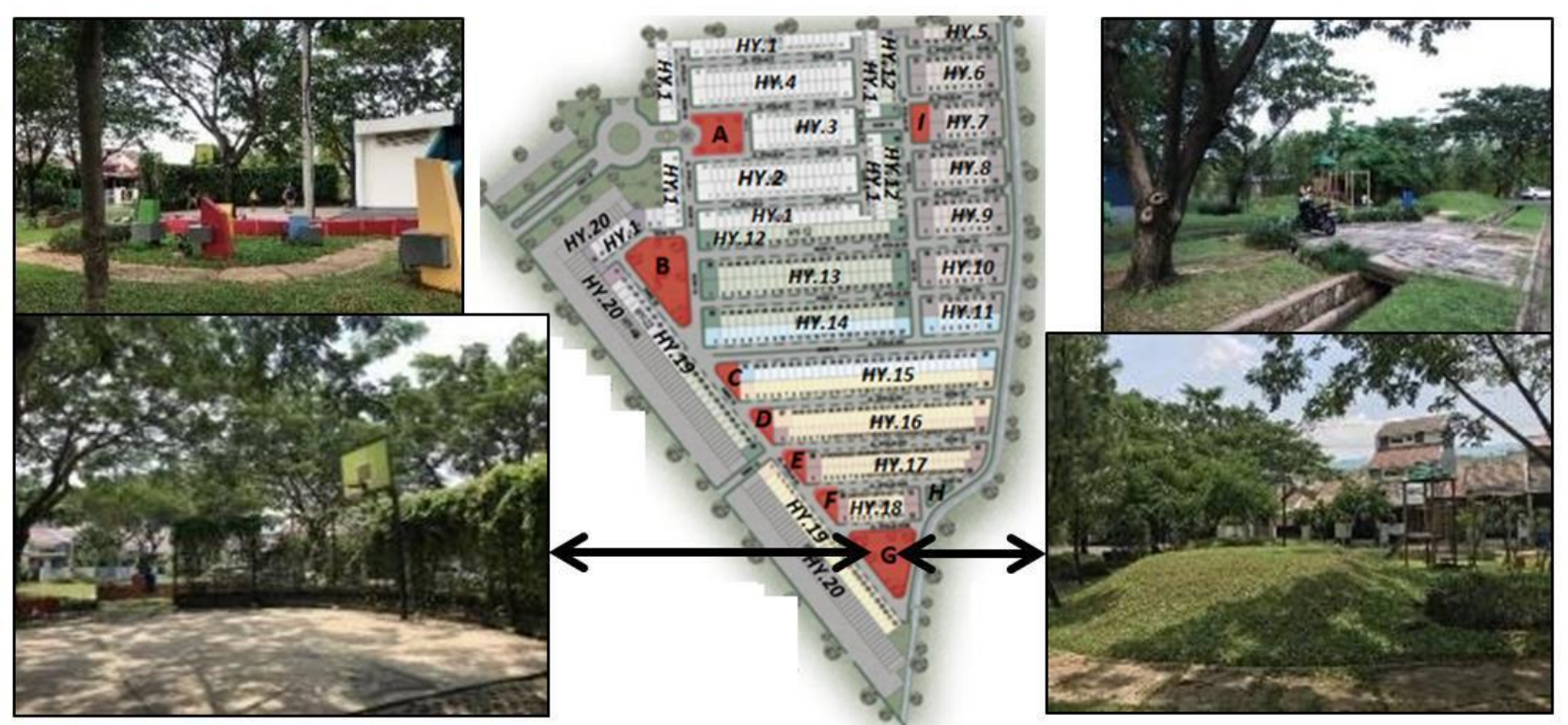

Figure 5. basketball court (red), children's games (blue), pedestrian areas (yellow), sitting area (green)

Exist of a physical element in the form of a basketball court (red) in an open space $\mathrm{G}$ allows wider interaction (not only between residents). While other physical elements that also invite users to move in the open space $\mathrm{G}$ are children's games (blue), and finally are pedestrian areas (yellow) which are sometimes used for walking. The sitting area (green) is not used by residents. 


\section{Social Interaction in Open Space A, B, G}

Type of activity in open space A, B, G is optional activity (child ren play, parents gather and chat while looking after children, parents walk around to get fresh air, and social activities between cluster residents. Activities that occur in the room open A, B, G triggers the process of social interaction called something happens because something happens where take place an activity triggers other activities (Carmona, M. 2004) (Carmona. 2010). Whereas, the pattern of social interaction that occurs in open spaces A, B, G is a secondary group, because users of this open space mostly come from residents who are around open spaces so that in this open space, residents only interact with neighbors around (Carr, Stephen.1992).

\subsection{Outdoor C, D, E, F and I}

In terms of placement, open spaces C, D, E, F and I are in the middle of neighboring groups, with a very small area compared to open spaces A, B and G. However, these open spaces have not become the focus of activities for surrounding homes, this is from the rare activity in this open space. These spaces are only for plants.

\section{The design form of Room C,D,E,F,I consists of 3 elements of activity (Figure 6)}

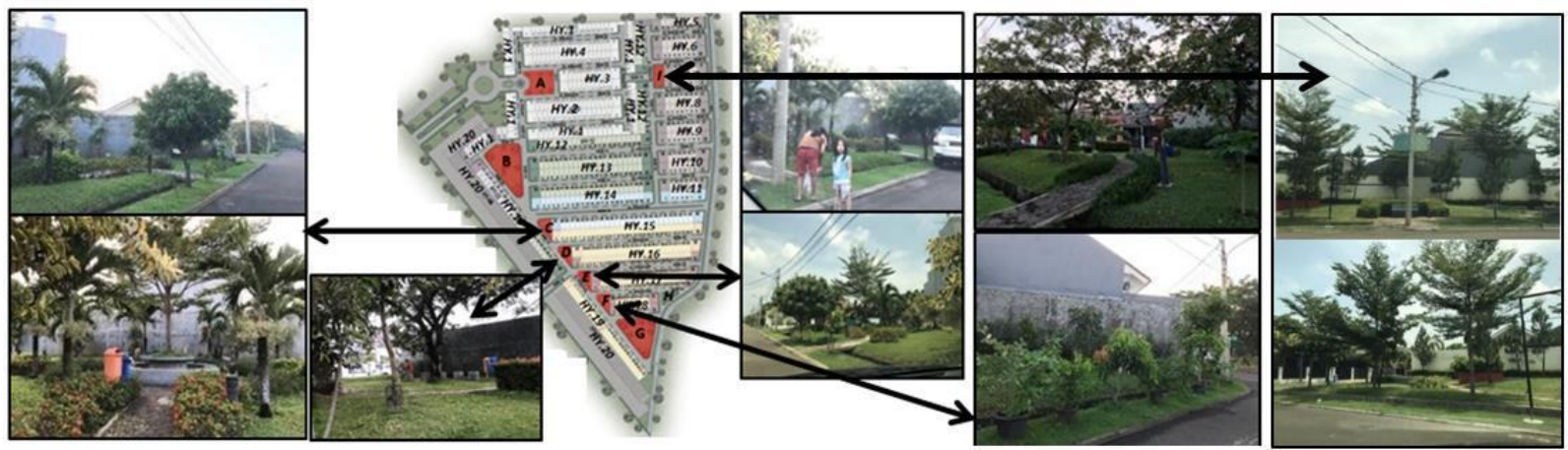

Figure 6. These spaces are only for plants

\section{Social Interaction in Open Space C, D, E, F, I}

Activities that occur in open spaces C, D, E, F, I belong to activities that need to carried out and social activities (occur in open spaces C, D, E, F, I only between people who already know each other). Activities that need be done in open space C, $\mathrm{D}, \mathrm{E}, \mathrm{F}, \mathrm{I}$ are to take a break while jogging. The use of these two open spaces is also rare and relatively brief, causing the process of social interaction that occurs in open spaces is a negative process (nothing happens because nothing happens) (Stevens, Q. 1997) where take place of an activity does not trigger another activity because the physical element is not attractive to all residents around.

\section{Conclutions}

From this research, it is known that the place, arrangement patterns, and physical elements of an open space related to one another.

Aspects that influence are human inhabitants around the housing complex, as well as outside the place area, due to beauty, comfort, from the layout of the physical parliament.

The most influential aspect of social interaction is the physical element of the open space, the physical element that drives the activity, without activity, the process of social interaction will not occur in existing open spaces. Exist of physical elements of open space than to act on find open space, because wherever there is an open space in the cluster, there will be no social interaction if there are no physical elements that are attractive to residents. The place and pattern of open space arrangement influence on the pattern of social interaction that form in each open space.

The pattern of open space arrangement itself affects distribute of the physical elements of open space, which in turn affects distribute of activities in open space.

\section{References}

Budiyuwono, H. (2014). Zone Room Occupancy Based Ethnic by User of Post-users in Tegal City. Dissertation Unpar. Bandung, Indonesia.

Carmona et.al. (2010). Public Space - Urban Space, The Dimension of Urban Design. 2nd Edition. Elseveier, Oxford.

Carmona, M., Marshal, S., \& Stevens, Q. (2004). Living Places: Caring for Quality.

Carmona. (2003). "Public Space Urban Space” The Dimention of Urban Design. London: Architectural Press London. 
Carr, S. (1992). Public Space. New York: Cambridge University Press.

Gehl, J. (1987). Life Betweet Buildings Using Public Spaces. New York: Van Nostrand Reinhold.

http://wartakota.tribunnews.com/2018/08/05/lima-tahun-penduduk-kota-bekasi-bertambah-1-juta-jiwa.

http://www.rei.or.id/sejarah.php.

https://gobekasi.pojoksatu.id/2017/03/10/20-tahun-kota-bekasi-jumlah-penduduk-dari-masa-ke-masa/.

https://id.wikipedia.org/wiki/Lego.

https://www.kompasiana.com/nabilrizki/5a2d1bc12a5823509c672ca2/ledakan-penduduk-mengancam-kota-bekasi

Madanipour, A. (2003). Why are the Design and Development of Public Spaces Significant for Cities? Dalam Designing Cities, Critical Readings in Urban Design; Cuthbert, A.R. (ed). Blackwell Publishing.

Profile of Damai Putra| Damai Putra Group.

Rapoport, A. (1977). Human Aspect of Urban Form, Perharman Press.

Shirvani, H. (1985). The Urban Design Process. New York: Van Nostrand Reinhold.

Stevens, Q. (1997). The Ludic City: Exploring the Potential of Public Spaces. Routledge, London.

Thiberg, S. (1985). Housing Research and Design in Sweden. Sweden: Byggforskningsrådet.

Untermann, R., \& Small, R. (1977). Site Planning for Cluster Housing. New York: Van Nostrand Reinhold.

Zhang, W., \& Lawson, G. M. (2009). Meeting and greeting : activities in public outdoor spaces outside high-density urban residential communities. Australia: Urban Design International. https://doi.org/10.1057/udi.2009.19

\section{Copyrights}

Copyright for this article is retained by the author(s), with first publication rights granted to the journal.

This is an open-access article distributed under the terms and conditions of the Creative Commons Attribution license (http://creativecommons.org/licenses/by/4.0/). 